\section{FILIAL PIETY AND CHASTITY IN NGUYEN DU'S THE TALE OF KIEU}

\author{
Montira Rato ${ }^{1}$
}

\begin{abstract}
The early $19^{\text {th }}$ century Vietnamese masterpiece, The Tale of Kieu by Nguyen $\mathrm{Du}$, is a story that famously highlights the conflict between the Confucian concepts of filial piety and female chastity, and between personal obligations and personal morality. This paper explores how issues of love and sexual relationships, as portrayed in the Tale of Kieu, influenced the thinking of Vietnamese intellectuals in the early $20^{\text {th }}$ century. Drawing on parallels to Kieu's plight, it is argued that the Vietnamese, who collaborated with the French, often made sense of their actions in terms of sexual submission and sacrifice as well as being compelled to prostitute themselves for the sake of a higher obligation - in their case to the nation. The portrayal of female sexuality and morality in Nguyen Du's story continued to be discussed by Vietnamese intellectuals well into the $20^{\text {th }}$ century. This paper charts the course of this debate and the wider discussions relating to sexuality and literature up until the 1945 August Revolution with the aim of showing how closely female chastity, Confucianism, and nationalism, came to be interlinked.
\end{abstract}

\footnotetext{
${ }^{1}$ Lecturer in Vietnamese language and literature, Department of Eastern Languages, Faculty of Arts, Chulalongkorn University
}

This study explores how issues of filial piety and chastity are portrayed and discussed in the early $19^{\text {th }}$ century Vietnamese masterpiece, The Tale of Kieu, by Nguyen Du. This long narrative poem recounts the plight of Kieu, a beautiful and talented young girl who has to prostitute herself in order to save her father from a corrupt mandarin. The story highlights the conflict between the Confucian concepts of filial piety and female chastity, personal obligations and personal morality. The Vietnamese who collaborated with the French in the early $20^{\text {th }}$ century saw themselves as torn by a similar conflict and claimed that, like Kieu, they had to prostitute themselves for the sake. The Tale of Kieu reflects the tension in the $19^{\text {th }}$ century Vietnamese society caused by the austere Confucian views of love, relationships and sexuality. It is hoped that the paper will contribute to an understanding of how closely the topics of female chastity, Confucianism and nationalist movements were connected.

The discussion and textual analysis is mainly based on the English translation by Le Xuan Thuy (1999) unless otherwise indicated. The study is divided into three main parts. Firstly, it will provide information on the authorial background and the socio-political context of The Tale of Kieu. Then, it will explore the ideas of love, filial duty and sexuality expressed in the story. In the final part, the discussion will be extended to the debates on The Tale of Kieu that dominated the academic and literary sphere in the early $20^{\text {th }}$ century.

\section{Nguyen Du and The Tale of Kieu}

Nguyen Du (1765-1820) was born in the village of Tien Dien, in the province of Ha Tinh. His father was a high-ranking 
official in the Le Dynasty (1428-1788). He was the seventh child of the family. Like several of his kin Nguyen Du served as a scholar and mandarin at Court. At the age of 17 he passed the official mandarinate examination and his career as a state official might have been brighter if the civil war between the Trinh and the Nguyen, two influential feudal families, had not taken place.

The country had been divided into two parts since the early $17^{\text {th }}$ century. The North was controlled by the Trinh while the South was under the Nguyen. While both families claimed that they recognized the Le Dynasty as the legitimate authority, they still fought against each other. However, after the long period of civil war, a local revolt, led by three brothers from the village of Tay Son, a province of Binh Dinh, was raised against the two families. The Tay Son rebellion was widely supported by downtrodden peasants and small merchants. In 1776, Saigon fell and Nguyen Anh fled the country and sought assistance in Siam. After that, the Tay Son defeated the Trinh in 1786. They then captured Hanoi (at that time known as Thang Long). However, with support from the French, Nguyen Anh defeated the Tay Son and in 1802 established the Nguyen Dynasty, under which the Vietnamese state became administratively unified for the first time. He became emperor Gia Long, and moved the capital city from Hanoi to Hue (at that time known as Phu Xuan).

Nguyen Du grew up during the civil war and his career endured a great many political vicissitudes. To show their loyalty to the Le Dynasty, Nguyen Du and some members of his family fought against the Tay Son. When he realized that the attempt was abortive, he refused to serve the new regime and returned to his home village instead. His career as mandarin was resumed when the Nguyen dynasty was established. Under the reign of Gia Long, he served as a provincial administrator, though a number of historians have speculated that he accepted the post reluctantly. In 1813, he went to China as a diplomat. It is believed that The Tale of Kieu was written during that diplomatic mission (Nguyen Loc 1999: 297 - 333).

The Tale of Kieu (also known as Kim Van $\mathrm{Kieu}$, the names of the protagonists) is based on a Chinese prose fiction that was written in the $16^{\text {th }}$ or early $17^{\text {th }}$ century. Nguyen Du rewrote this short novel into 1,627 couplets, that is a 3,254-line poem, in the folk metre known as luc bat or 'sixeight' verse. The author borrowed the plot from a Chinese prose narrative but adapted the details, characters and atmosphere of the story into a Vietnamese context (Duong Quang Ham 1942: 104). It tells the story of Vuong Thuy Kieu, a beautiful and talented girl, who was born into a middle-class family. When her father, Mr. Vuong, a merchant who is described as 'neither rich nor poor', is arrested on a false charge, in order to rescue him she sells herself as a concubine and is later forced to become a prostitute.

Because of the author's literary talent and its moving content, the story was loved by an audience from all walks of life. However, Vietnamese Confucian scholars did not consider a story about a prostitute to be as worthy as were the Chinese classics (Huynh Sanh Thong 1984: 99 125). This contradiction between the popular reception and literary standards can probably be explained by reference to the Confucian concept of the role and function of literature. Traditionally, the 
literature of learned scholars was written in Chinese and was dominated by the Confucian concept of van so di tai dao da, which literally means 'literature carries morality'. That is to say, the purpose of literature is to enhance morality (Dinh Gia Khanh 1998: 25 - 26). As the majority of the Vietnamese population was illiterate, only the ruling class and scholars were involved in literary activities and they were mainly concerned with political stability and moral standards. As a result, literature was almost completely excluded from the vernacular world. Good literary works had to represent the social order and morality as prescribed by the royal court.

However, from the late $18^{\text {th }}$ century, the writers of Nom stories paid more attention to ordinary people. Nom stories are written in the demotic script, which is an ideographic script used to transcribe the Vietnamese language, while Han or Chinese was the official language. The oldest text written by Nom dates from the $14^{\text {th }}$ century but the script itself might have been created earlier than that. Nom is regarded as a reaction against the domination of Chinese culture and civilisation. Literature in Nom was highly developed in the $17^{\text {th }}$ and $18^{\text {th }}$ centuries. Nguyen Du's The Tale of Kieu followed this literary trend. (Nguyen Loc 1999: 652)

\section{Filial Piety and Chastity in The Tale of Kieu}

It is said that young Vietnamese were taught not to read the story of Phan Tran and The Tale of Kieu. As is shown in an old saying:

men should not tell the story of Phan Tran, women should not tell the story of Thuy Van and Thuy Kieu.

(quoted in Dinh Gia Khanh 1998: 27)

In the $18^{\text {th }}$ century work 'Phan Tran', it is arranged that Phan Sinh, the main character in the story, will marry a girl chosen by his parents, but he falls in love with another girl. He is also obsessed with his love and this affects his study. The plot is contrary to the Confucian idea of filial piety that a child must obey his or her parents even in marriage. As for Kieu, she manages to meet her sweetheart, Kim Trong, in private when her family is away and she agrees to be his wife without the approval of her parents. Such behaviour was unthinkable in the Confucian period. The emperor Tu Duc pointed out that The Tale of Kieu was for entertainment and that one should not take the story seriously (ibid). Also, throughout the period of 15 years that she is separated from her family, Kieu lives with three different men. Vietnamese scholars commented that neither of these stories was worth reading because Phan Sinh's and Kieu's characters did not conform to the main concepts of Confucianism.

The Tale of Kieu can be seen as a challenge to Confucian morality. Nguyen Du's masterpiece is not only contrary to the Confucian teaching on female chastity, but it also reacts against the strict concepts and secretiveness of Confucianism in favour of love and sexuality. In addition, it can be said that it was uncommon for a Confucian scholar in the early $19^{\text {th }}$ century, like Nguyen Du, to introduce into a literary work the topics of love and sexuality, which, it was thought, should be kept hidden and clandestine. 
A study by Anthony Giddens, although dealing with Western society, helps clarify why authors in traditional societies were not encouraged to explore the issue of love. As Giddens notes, in Western literature, romantic love was first mentioned in the late $18^{\text {th }}$ century narratives. This is because love had been considered a disruptive and dangerous force. Passionate love had the power to sway a person from his or her routine and duty, to stimulate him or her into radical action and to turn his or her back on existing institutions. Love was also associated with 'freedom and selfrealisation' (Giddens 1992: 38 - 40). As is shown in this story, Kim Trong and Kieu ignore the old tradition because of their love. However, in a Confucian society such as Vietnam, women, not men, are the focus of denunciation for that improper behaviour (Nguyen Ngoc Thien 2002: 579).

In the opinion of a prominent literary critic, Tran Dinh Huou, according to Confucian standards, a good piece of literature should avoid extremism and maintain moderation. As he points out:

For Confucian scholars, a literary work should help distinguish between good and evil but the degree of criticism should be moderate not extreme. Topics that should be strictly avoided in a literary piece include lewdness and sexual desire because writing about sex and desire is regarded as illicit and immoderate. Also, literary criticism, when used as a means of denouncing evil, should be expressed in a moderate way and not be too explicit.

(Tran Dinh Huou 1991: 19)
Thus, not only the scene where the young lovers arrange to meet each other in private, but also the details about brothels and prostitution in The Tale of Kieu would be regarded as extreme according to Confucian standards of good literature. These include such explicit details as a prostitute using a little juice from the peel of pomegranate and a few drops of chicken's blood to fool customers that she is a virgin, and the way in which girls at a brothel are taught about the arts of love, including the seven sentimental ways of speaking with customers and the eight techniques of entertaining them. Also included is the way Nguyen Du describes the body of Kieu in detail:

Through the light rosy gauze curtain,

The silhouette of her body stood out,

As white and transparent as if it were made of jade and ivory.

It resembled truly a perfect statue and a divine masterpiece. (p. 189)

In the story, she is first sold as a concubine to Ma Giam Sinh. Then, she is transferred to a brothel run by a depraved woman named Tu Ba. After that, she becomes a concubine of Thuc Ky Tam, a good man whose wife, Hoan Thu, is very jealous. Treated badly by Thuc's wife, Kieu decides to flee but, unluckily, she meets bad people who return her to the brothel. Later, she is rescued by Tu Hai, a rebel leader. Her life would then have been happy had she not believed Ho Ton Hien, a corrupt mandarin, and asked Tu Hai to surrender to the court. This leads Tu Hai to his death.

On learning that she has been cheated by Ho Ton Hien and that her advice has led Tu Hai to his death, Kieu is devastated. 
When the mandarin then announces that she is to be given to his officer, Kieu decides to take her own life by jumping into the river, as the only way of saving herself from a shameful life and a cruel fate. The poet Tan $\mathrm{Da}^{2}$ also reproached Kieu for not killing herself after the death of Tu Hai. Tan Da expressed his feelings about this episode in The Tale of Kieu as follows:

Two lines of tears, two waves,

Half a husband's funeral, half a lord's feast.

If only the governor had taken pity on that ill-fated woman,

The Tien Duong river might not have entombed the one with rosy cheeks!

(quoted in Nguyen Hien Le 1996: 42)

It can be said that, in The Tale of Kieu, Nguyen $\mathrm{Du}$ broke the traditional convention of Vietnamese literature by not highlighting chastity. Instead, the author raised the conflict between filial piety and chastity; that is, Kieu cannot keep her chastity because of her filial piety. She sells herself in order to save her father. A question relating to Confucian teaching occurs: should Kieu be judged on her filial piety or on the loss of her female chastity, when this loss of chastity (bat tiet) is in fact due to her filial piety? Another crucial contradiction is whether or not the filial piety of a woman with a pure heart, who sacrifices herself for the survival of her

\footnotetext{
${ }^{2}$ Tan Da is a pen name of Nguyen Khac Hieu. He was born in 1889 in a Confucian family and became a famous Vietnamese poet in the early $20^{\text {th }}$ century. For more detail, see Huynh Sanh Thong. 1996. An Anthology of Vietnamese Poems from the Eleventh through the Twentieth Centuries. New Haven: Yale University Press.
}

father, represents her salvation or her physical degradation? As for Nguyen Du, he openly shows his sympathy for his main character:

The perfume of your faith has reached Heaven

Selling yourself to save your father is an act of filial devotion, Saving another person is an act of altruism,

You have served your country and your people faithfully. (p. 370)

By contrast, for Confucian literati, the acceptance of this contradiction seems impossible. The comment of the Confucian scholar and poet Nguyen Cong Tru (1778-1858) is a good example of the Confucian view of female chastity. As he says:

...From Ma Giam Sinh to Tu Hai To sell her dying body and live in brothels.

Where is Kieu's filial piety now?

And then he draws a harsh conclusion:

Miserable life did not give her chastity

Misfortunes only lead her to promiscuity.

(Nguyen Loc 1999: 438)

Kieu is not the mistress of her own destiny. Her life is controlled by bad fate. Nguyen Hien Le (1996: 36) pointed out that The Tale of Kieu "is a story that portrays the human condition - or, more accurately, the condition of a talented and beautiful woman - face to face with destiny". The Buddhist concept of Karma is also shown in the story. The scholar Tran Trong Kim asserted that if one understands The Tale of Kieu, one can 
understand a part of Buddhism. On the other hand, knowledge of Buddhism can help readers understand The Tale of Kieu more clearly (reprinted in Nguyen Ngoc Thien 2002: 568). The following example shows how the idea of Karma is portrayed in the story. As revealed in the story, the bad characters like Ma Giam Sinh or Tu $\mathrm{Ba}$ are punished. Meanwhile, the good people like Kieu are rewarded after they have paid off their sins. As shown at the end of the story, Kieu can enjoy the reward of her good deeds.

....and her previous sins have been washed out.

Sometimes, heaven is also indulgent to the human beings:

Those who have paid off their previous debts,

May expect compensation in their sentimental future. (p. 367)

After having heard about Vuong's misfortunes and the sacrifice of Kieu, Kim Trong responds to Kieu's request by marrying Thuy Van, Kieu's younger sister. He never gives up searching for Kieu. Towards the end of the story, Kieu is rescued by a Buddhist nun and returned to her family and loved ones. Here, the idea of love is conveyed interestingly as it is revealed that the subsequent marriage between Kieu and Kim Trong is not consummated. They decide to live together as friends instead of as husband and wife. As shown in the story:

Of love and friendship they fulfilled both claims-

They shared no bed but joys of lute and verse.

Now they sipped wine, now played a game of go,

Admiring flowers, waiting for the moon.
Their wishes all came true since fate so willed,

And of two loves marriage made two friends.

(Huynh Sanh Thong 1996: 167)

Thus, their love is not connected to sexuality, drawing a sharp contrast with the sexuality of the prostitution in which Kieu engaged during 15 years of misery. In fact, this kind of platonic love was new to the social context of the early $19^{\text {th }}$ century Vietnam. Traditionally, in Vietnamese society, marriage was not based on love but on an agreement between two families. Thus, it was determined by consideration of factors such as wealth, social status and reproduction, love not being taken into account. Marriage was related to reproduction and economic imperatives, and women had to rely entirely on men.

Traditionally, Vietnamese women were controlled by 'tam tong' or the three submissions, which divided a woman's life into three stages: when she was young, she had to obey her father; when married, she depended on her husband; if her husband died, she had to obey her eldest son (Marr 1984: 192). Similarly, the relationships in the society were mainly categorised into the 'tam cuong', the three social bonds, which included the relationships of ruler-subordinate; fatherson; and husband-wife (Pham Van Khoai 2003: 65). Thus, the platonic love between Kieu and Kim Trong would not be imaginable at the time the poem was composed. Moreover, a friendship between a man and a woman, as demonstrated in the relationship of Kieu and Kim Trong, did not fit any of the types of social bonds described by Confucius. 
It is generally believed that Kieu's destiny is analogous to that of Nguyen $\mathrm{Du}$, especially the relationship between Nguyen Du and the Nguyen rulers. If the relationship of the couple in The Tale of Kieu does not reflect the Confucian concept of social relations, then similarly the relationship between the poet and the Nguyen Dynasty was also an awkward one according to Confucian ethics. Kieu's anxiety as to whether or not she should ask Tu Hai to surrender to the royal court can be compared to Nguyen Du's dilemma about whether or not he should serve the Nguyen lords. In the end, she chooses to follow Confucian teaching on filial piety and loyalty to the king and this is similar to Nguyen Du's decision to serve the Nguyen Dynasty while remaining very loyal to the Le Dynasty.

How much honour I could do to myself and to my parents!

I would work first for the interest of my country,

And then for that of my family.

By so doing, I could fulfil my two main duties;

My filial piety towards my parents And my devotion towards the sovereign. (p. 342)

Despite having been regarded as a good and honest mandarin, Nguyen $\mathrm{Du}$ was accused of having tam su hoai Le, that is having concern for or obsession with the Le Dynasty. If his highly successful narrative poem revealed his doubts about Confucian morality, then it is quite ironic that he himself was trapped by the dilemma caused by the Confucian value of 'trung' or faithfulness. Nguyen Du's internal conflict is more clearly expressed in a poem he wrote about Thang Long (or Hanoi in the present day):
A woman does not have two husbands,

How could one wander around and look for a new king.

(Nguyen Loc 1999: 313)

Like Kieu, who could not keep her chastity, Nguyen Du suffered because he could not maintain his faithfulness to the Le Dynasty even though he knew that he was unable to turn against the social and political turmoil. As depicted in the beginning part of The Tale of Kieu:

A hundred years - in this life span on earth

Talent and destiny are apt to feud.

You must go through an event in which the sea becomes mulberry fields

And watch such things as make you sick at heart.

(Huynh Sanh Thong 1996: 3)

Confucianism was officially introduced into Vietnam in the $10^{\text {th }}$ century. Ngo Quyen, the founder of the Ngo Dynasty, declared independence in 938 and established Vietnam as a nation state after it had been under Chinese rule for more than a thousand years. Nevertheless, he imitated the Chinese model of administration with its Confucian ethics. Confucianism subsequently declined in the $13^{\text {th }}$ and $14^{\text {th }}$ centuries during the Ly-Tran Dynasty due to favour then being given by the Court to Buddhism but it flourished again during the Le Dynasty between the $15^{\text {th }}$ and $18^{\text {th }}$ centuries. The ambiguous morality in Nguyen Du's The Tale of Kieu reveals the decline in the acceptance of Confucianism in the $19^{\text {th }}$ century. Moreover, Nguyen Du's attitude towards social and political change, as shown in the story, was also articulated by Vietnamese literati in the early $20^{\text {th }}$ 
century and this is the topic that we are going to discuss in the next part of this study.

\section{Debates surrounding Kieu: a move towards Modernity}

Although the story of Kieu was popular and widely admired by Vietnamese people of all classes, it received considerable attention and became a controversial topic for academic discussion in the pages of newspapers and magazines in the early $20^{\text {th }}$ century. Pham Quynh, the former editor of Nam Phong (Southern Ethos), accused of being a collaborator with the French colonial government, prompted The Tale of Kieu to be discussed among scholars. Since the early 1920 s, the Nam Phong journal had been dedicated to the issue of women's rights. The conflict of how individuals were affected by Confucian doctrine, which focused on the duty of a person towards his or her family and society, was constantly raised in a number of journals and magazines. This process reflected the decline of Confucianism and the growing influence of Western ideas of individualism and egalitarianism. In 1920, with French participation, Pham Quynh organised a celebration to mark the centennial of Nguyen Du's death. In 1924, he wrote a controversial essay entitled 'Bai Dien Thuyet bang Quoc Van' (The Speech by National Language). In this essay, Pham Quynh stated that The Tale of Kieu was the nation's masterpiece and that only literature could reflect a nation's true spirit. He wrote:

If The Tale of Kieu exists, our language exists. If our language remains, our nation will remain, and there is nothing that we should be concerned about or afraid of. We should not doubt it.

(Nguyen Ngoc Thien 2002: 385)

His comment soon brought a response and a large portion of the journals and magazines became dominated by the resulting discussion and debate on The Tale of Kieu. As the Confucian scholar Ngo Duc Ke, who was imprisoned at Con Son Island for 15 years for taking part in the anti-colonial movement, complained:

In our country these days, there are so many literary reviews of Kieu, studies of the character Kieu, essays that show appreciation of Kieu, songs about Kieu, opera and plays about Kieu, portraits of Kieu. We can see Kieu everywhere.

(quoted in Nguyen Loc 1999: 443)

But Pham Quynh's belief in the power and importance of literature was strongly opposed by nationalists and Confucian scholars. They believed that Pham Quynh, as a French lackey, only wanted to sway the interest of young Vietnamese away from the political struggle to seemingly harmless literary issues. For example, Ngo Duc Ke strongly emphasised that language and literature could be maintained only when the people and nation survived first (Marr 1984: 154).

It should be noted that prostitution was used, under French rule, as a metaphor for collaboration with the French. Relating their plight to that of Kieu, those who collaborated with the colonial government explained that they prostituted themselves for the development and modernisation of the country (Huynh Sanh Thong 1984: 106). Not surprisingly, their claim was 
strongly rejected by the nationalists. It is also noticeable that the evaluation of Kieu was clearly divided between two sides, those who praised Kieu as being filial and those who criticised her as unchaste. For example, the nationalist Huynh Thuc Khang called Kieu a whore and said that the poem was pornographic (Nguyen Ngoc Thien 2002: 586). However, this criticism probably aimed at the French collaborators, the advocates of Kieu, rather than at the literary work itself.

Apart from the fact that The Tale of Kieu was utilised for political ends, the analysis of it by a literary critic, Nguyen Bach Khoa, through the application of Western psychology was a striking development in the Vietnamese literary and academic domain. According to this analysis by Nguyen Bach Khoa, also known as Truong Tuu, Kieu suffers from hysteria, and the author Nguyen $\mathrm{Du}$ suffered from depression when he wrote the poem. Although Nguyen Bach Khoa's paper created a controversy about the study of science and art, it was not well received. For example, the well-known critic Hoai Thanh, and the poet, Luu Trong Lu, viewed Nguyen Bach Khoa's review of The Tale of Kieu as too academic and scientific and his approach as somehow unsuitable for literary studies (for further information see Nguyen Ngoc Thien 2002). Even so, Nguyen Bach Khoa's essay on The Tale of Kieu significantly marked a transition from the Confucian period to the Modern period. From then on the new generation of Vietnamese literati began to move away from a Confucian worldview and towards a perspective based on science and the new knowledge imported from the West. At least, they had new explanations for life and social circumstances.
Today, Nguyen Du is regarded as a peerless national poet and The Tale of Kieu as undeniably a national epic. With its literary merit and universal theme on love, the poem stands the test of time. Moreover, Nguyen Du, through his characterisation of Kieu, knotted the tie of love with filial duty and revealed the ambiguity of the Confucian concept of female chastity. The topics of love, Confucian morality and social obligation drawn from The Tale of Kieu in the early $20^{\text {th }}$ century public debate provided a realm for the liberation of ideas for the new generation of Vietnamese intellectuals and removed the limitations of Confucian ideology. If Pham Quynh and the French colonialists really wanted to turn young Vietnamese minds from political struggle, then ironically, discussion of the miserable life and adventures of the prostitute in Nguyen Du's best known work gave a great opportunity for the nationalists to spread their ideas. The process of transforming Confucian society into Modernism was also favourable to the Communists' preparation for the August Revolution but this is a topic to be discussed in another project.

\section{References}

Dinh Gia Khanh (ed). 1998. Van Hoc Viet Nam The Ky X-Nua The Ky XVIII (Vietnamese Literature during the $10^{\text {th }}-$ the first half of the $18^{\text {th }}$ century). Hanoi: Nha Xuat Ban Giao Duc.

Duong Quang Ham. 1942. Viet Van Giao Khoa Thu (Textbook for Vietnamese Literature). Hanoi: Nha Hoc Chinh Dong Phap.

Giddens, Anthony. 1992. The Transformation of Intimacy: Sexuality, 
Love and Eroticism in Modern Societies. Oxford: Polity Press.

Hoang Xuan Han. 1997. Noi ve Truyen Kieu (Talking about The Tale of Kieu). Tap Chi Van Hoc 3: 3-15.

Huynh Sanh Thong. 1984. Main Trends of Vietnamese Literature between the Two World Wars. The Vietnam Forum 3: 99-125. 1996. An Anthology of Vietnamese Poems from the Eleventh through the Twentieth Century. New Haven: Yale University Press.

Le Dinh Ky. 1996. Tinh Nghia tu Truyen Kieu (Love and Fidelity from The Tale of Kieu). Tap Chi Van Hoc 10: 18-20.

Marr, David G. 1984. Vietnamese Tradition on Trial 1920-1945. Berkeley: University of California Press.

McHale, Shawn Frederick. 2004. Print and Power: Confucianism, Communism, and Buddhism in the Making of Modern Vietnam. Honolulu: University of Hawai'i Press.

Nguyen Du. 1983. The Tale of Kieu. Translated by Huynh Sanh Thong. Binghamton: Yale University Press. 1999. Kim Van Kieu.

Translated by Le Xuan Thuy. Hanoi: Nha Xuat Ban Van Hoc.

Nguyen Hien Le. 1996. The Human Condition in The Tale of Kieu. The Vietnam Review 1 (autumn-winter 1996).
Nguyen Loc. 1999. Van Hoc Viet Nam nua cuoi the ky xviii - het the ky xix (Vietnamese Literature from the Late $18^{\text {th }}$ Century to the Early $19^{\text {th }}$ Century). Hanoi: Nha Xuat Ban Giao Duc.

Nguyen Ngoc Thien. 2002. Tranh Luan Van Nghe the ky XX (Debates on Literature and Arts in the $20^{\text {th }}$ Century). Hanoi: Nha Xuat Ban Lao Dong.

Pham Van Khoai. 2003. Giao Trinh Han Nom danh cho Du Lich (Han - Nom Textbook for Tourism). Hanoi: Nha Xuat Ban Dai Hoc Quoc Gia Ha Noi.

Tran Dinh Huou. 1991. Ve anh huong nhieu mat cua nho giao trong van hoc viet nam co can dai (The Influences of Confucianism on Classical Vietnamese Literature). Tap Chi Van Hoc 3. 